dynasty when they might be expected. Four separate and distinct defensive systems have been differen. tiated, of which the earliest, belonging to the Early Bronze Age (c. 2500-2100 B.c.) rested on deposits of a still older period. The period of the city's greatest expansion was in the third phase (Middle Bronze Age II), which is marked by a cultural change. Under the Hyksos at that time, the city walls were much extended; and the character of the Palace and other buildings suggests that Jericho, as the residence of a Hyksos governor, had become a city of more than local importance. This phase comes to an end at about 1600 B.c. when the city was destroyed, presumably by the Pharaohs. It was rebuilt, but restricted within the bounds of the earlier area of occupation. From that time onward its history can be traced by means of scarabs and painted pottery having a range of dates between 1600 and 1400 B.c. At the latter date under Amenophis III the normal life of the city ceases abruptly. All the buildings of the Palace area and the few houses against the city wall bear witness to a great catastrophe-the indications are an earthquakefollowed by an intense fire while the rooms were in occupation. Thenceforward until about 900 в.c. the site was practically deserted.

\section{Sixth International Congress for Scientific Management}

Considerable progress is being made with the organisation of the Sixth International Congress for Scientific Management, which is to be held in London on July 15-18, 1935. A strong council which includes representatives of societies connected with various phases of scientific management has been formed. H.R.H. the Prince of Wales is the patron of the Conference and Government support has been promised. The chairman is Sir George Beharrell, managing director of Dunlops. The chairmen of the various committees are Dr. E. F. Armstrong (Organisation), Sir Henry Fowler (Technical) and Mr. G. R. Freeman (Finance). Mr. H. Ward, formerly general secretary of the National Institute of Industrial Psychology, has been appointed secretary. It is hoped that the Congress will demonstrate that British industry and British technicians are fully alive to the importance of scientific principles in management. Many highly skilled organisations exist, which are using and propagating these principles, but the Congress should help still further to stimulate the national movement in this direction and to create a general appreciation of the applications of management to organised industrial and commercial activity. Among the questions which will be discussed are: concrete examples of the application of scientific management to distribution problems in manufacturing, wholesaling and retailing; methods of controlling production; methods of selection, education and training of personnel suitable for high administrative positions; correct methods of inculcating modern management principles and practices in large-scale, medium and small undertakings, and the rôle of trade or other associations in this field.

\section{Glass-Making}

THE Friday evening discourse at the Royal Institution on December 8 was delivered 'Ny Major R. M. Weeks, a director of Messrs. Pilkington Brothers, Ltd., on "The Making of a Sheet of Glass". Major Weeks first gave a brief outline of some fundamental scientific considerations, with special reference to composition, the tendency to devitrify, and the resistance of the product to weathering. Melting is carried out by one of two processes, namely, the older method in which the raw materials are placed in pots in a gas-fired furnace, and the modern method by which the raw materials are introduced at one end of a continuous furnace and the molten glașs withdrawn at the other. The various processes necessary for the manufacture of sheet and plateglass were described in detail. Films were shown of the hand-blown and the machine.drawn cylinder sheet glass processes. The latter has been superseded by the flat-drawn process, in which the sheet is drawn in the form of a flat continuous ribbon. To illustrate the manufacture of plate glass, an interesting film of the Bicheroux casting process was shown and reference was made to the latest process of plate glass manufacture, the flow process, in which the molten glass is delivered to rollers which form a continuous ribbon of glass. In the modern continuous grinding and polishing machine the glass plates, laid on a moving bed, pass successively under the grinding and polishing machines. The discourse concluded with a description of two novel forms of flat glass of interest, namely, opaque glass manufactured in black, white and various colours and known as vitrolite; and toughened glass, known as 'armourplate' or 'triplex toughened', which has a high resistance to fracture combined with the property, if broken, of shattering into small harmless fragments.

\section{India and Displaced German Scientific Workers}

Although the creation of special posts and the raising of supplementary funds for research work have alleviated in some degree the difficulties attendant on the absorption of displaced German Jewish teachers and students, these measures have not been adequate to provide for all, or to meet all contingencies. In India, where the appeal on behalf of the displaced workers has met with a sympathetic reception in certain quarters, the posts which might be made available are extremely limited in number, and in the matter of academic and research appointments, India has its own special difficulties which militate against even limited assistance. In each year India produces a relatively large number of men trained in science, including many with qualifications obtained in Europe. In present conditions these find difficulty in obtaining appointments in India. In an interview with Acharya Roy, which appears in the Amrita Bazar Patrika of November 14, relating to the appeal on behalf of Jewish men of science, reference is made to the virtual monopoly enjoyed by Europeans in posts for scientific research in India, against which Indian research students have made way only very slowly in the last fifteen ycars. Acharya Roy points 
out that these difficulties would be greatly enhanced if any attempt were made to absorb German men of science, while they might resent being placed in a position of subordination to Indian workers. His attitude towards the employment of Europeans in research in India provides much food for thought, and suggests that the educational situation of the future will call for tactful handling unless Indian education is to suffer. In the course of his interview, however, Acharya Roy does point out a weakness in the position of the European teacher, who, as an exile, looks forward to his return home, and as a foreigner cannot enter intimately into the life of his students.

\section{Classification of Sinanthropus}

When Dr. Hrdlička was passing through the press the revised edition of "The Skeletal Remains of Early Man" (Smithsonian Miscell. Collect., Vol. 83, 1930) he received a description, accompanied by photographs, of the then recently discovered skull of Peking man. Although it was too late for reference in the text, in an addendum Prof. Hrdlička gave it as his opinion that the skull was neanderthaloid, resembling the Galilee skull, and that "had it been found in Europe or in Asia Minor it would hardly be taken by any expert student . . . as anything else than neanderthaloid". Dr. Hrdlicka has now made a careful examination of cranial and endocranial casts of the Peking skull recently received from London, examining them side by side with comparable material in the National Museum collections at Washington. According to a communication issued by the Smithsonian Institution of Washington, Dr. Hrdlička finds that his previous conclusions are fully substantiated. They are in complete agreement with the view recently put forward by Dr. E. Dubois before the Dutch Academy of Sciences, being in effect that Peking man is a somewhat variant member of the widespread Neanderthal race. Though the brain and skull are small, Dr. Hrdlička holds that the former is "thoroughly human", if low in type, while the latter is comparable in capacity with the skulls of prehistoric Peruvians in the Washington collections, of which some thirty in number are less than 1,050 e.c. in cubic capacity. In respect of both characters, Peking man is thus brought well within the range of the human.

\section{Guiding Aeroplanes when about to Land}

IN the radio range-beacon system now used on American airways, it is sometimes very difficult to determine the absolute direction of the aeroplane when it is near the radio beacon. The pilot can easily pass from one quadrant to another without knowing it. When once so lost, he may wander many miles from the beacon before he can find out which quadrant he is on. Tests show that the average pilot, when flying under the hood and purposely lost, requires about an hour to find his course. In the Journal of Research of the Bureau of Standards for September, Mr. F. W. Dunmore describes aural, visual and combined methods which enable the pilot to identify the quadrant with certainty. In the aural method, directive signals are sent out; a one dot signal in a westerly direction, two dots easterly, three dots north and four dots south. Depending on which set of these signals is the loudest, a pilot can determine his general direction from the beacon. During an interval between the sending of the beacon station identification letter, the one dot and two dot signals are sent out, and during the next interval the three dot and four dot signals are transmitted; which two of the four sets of signals are heard loudest enable the pilot to determine his course. In the visual system, use is made of an indicator the reeds of which are affected by the signals, and their relative amplitudes enable the course to be determined. An advantage of the system for course and quadrant identification is that it can be readily applied to existing beacon stations as it requires no alterations to the antenna structure. Photographs of the devices and full diagrams of the necessary circuit arrangements are given.

\section{Inductive Interference with Telephone Lines}

THE working of telephones is often seriously impaired by the noise due to induction from neighbouring power or railway lines. This problem has been closely studied by electrical engineers for the last thirty years. In a paper communicated to the Institution of Electrical Engineers on November 23, Mr. W. G. Radley and Dr. S. Whitehead show that rapid progress has been made in the solution of the problem during the last few years. The amount of the interference in any given case can now be deter. mined quite definitely by mathematics. It is due both to electromagnetic and electrostatic induction and also in some cases to radio effects. The loss in the 'articulation' of a telephone depends on the frequency of the disturbing voltage. For example, to produce the same loss in articulation by means of a note having a frequency of 150 as a note having a frequency of 1050 , at which the maximum disturbance occurs, the induced voltage would have to be increased 158 times ( 22 decibels). The Post Office has now made a 'noise' meter which gives at one reading the magnitude of the interference factor produced by all the induced harmonics. It is a great step in helping the electrical industry to know that interference with existing telephone systems by any projected power or railway scheme can now be predetermined in advance. If it is too great, it can be decreased by a suitable choice of generators, the use of power cables or telephone cables instead of overhead circuits, etc. When there is a short circuit on the power line, and there are large transitory earth currents, there is risk both of electric and acoustic shocks. These may be partly mitigated by protective devices.

\section{Thermodynamic Storage of Energy}

THE equalising of the normal daily load of an electricity works with its sudden 'peaks' and deep drop at night is one of the fundamental problems of electrical engineering economics. The suggestions recently made that many of the European power 